\title{
EFFECT OF INTERCROPPING CARROT (Daucus carota L.) WITH FRENCH MARIGOLD (Tagetes patula nana L.) AND POT MARIGOLD (Calendula officinalis L.) ON THE OCCURRENCE OF SOME PESTS AND QUALITY OF CARROT YIELD
}

\section{${ }^{1}$ Beata Jankowska, ${ }^{2}$ Elżbieta Jędrszczyk, ${ }^{2}$ Małgorzata Poniedziałek}

\author{
${ }^{1}$ Department of Plant Protection \\ ${ }^{2}$ Department of Vegetable and Medicinal Plants \\ Faculty of Horticulture, University of Agriculture in Kraków, 29 Listopada 54, 31-425 Kraków, Poland \\ e-mail: jankowskab@ogr.ur.krakow.pl
}

Received: 17.03.2012

\begin{abstract}
Intercropping combines different aspects of the interaction between organisms in ecosystems and may be classified as a pro-ecological method of plant cultivation limiting the harmful human interference in the environment, especially the use of chemicals. It also allows high yield, good quality, and economic productivity to be achieved. The aim of the present study, conducted in the years 2003-2004 in Mydlniki near Kraków, was to determine the effect of intercropping carrot Nardin $\mathrm{F}_{1}$ with French marigold (Tagetes patula nana L.) 'Kolombina' and pot marigold (Calendula officinalis L.) 'Promyk' on carrot yield, its quality, and the occurrence of pests. On average in both years of the study, intercropping did not reduce total or marketable carrot yield. In 2003 intercropping contributed to a significant increase in marketable yield compared with yield from sole cropping. In 2004 the dry matter content was higher in the roots of carrots grown with pot marigold. The treatments intercropped with both French and pot marigold were characterized by an increased content of sugars in carrot roots and in 2004 year - of carotenoids. Intercropping had a significant effect on the number of roots damaged by the carrot rust fly, Psila rosae, (the best in this respect was the combination with Tagetes) and by nematodes (the best in this respect was the combination with Calendula). The number of larvae of carrot psyllid, Trioza viridula, was significantly lower in the plots where carrot was intercropped. The study did not find intercropping to have a positive effect on reducing the occurrence of the root aphid.
\end{abstract}

Key words: Daucus carota, quality of yield, companion plants, carrot rust fly, root aphid, carrot psyllid, nematodes

\section{INTRODUCTION}

Carrot has been grown for many years in different regions of Poland and has become a natural habitat for many pests (M ichalik and Wiech, 2000; Szwejda and Wrzodak, 2007). To obtain high yield of good quality, growers seek opportunities to reduce the damage caused by some pests of carrots. Chemical carrot protection is expensive and sometimes unacceptable (e.g. in baby-food products). More and more often non-chemical methods of plant protection are used. One of them is intercropping. The relationship between intercropped components has become a point of interest for many authors as environmental resources management with respect to productivity and economic indicators ( $\mathrm{Ne}$ to et al. 2010). Foraging adults of phytophagous insects are attracted by host-plant volatiles and supposedly repelled by volatiles from non-host plants. The host-plant-finding behavior of insects may be disrupted by the close comparison of two plant species. A n d ow (1991) analyzed 209 studies involving 287 pest species. Compared with monocultures, in mixed cropping the population of pest insects was lower by $52 \%$ (149 species). Numerous studies have shown that mixed cropping of carrots with some plants reduced carrot damage by some pests ( $\mathrm{Uwah}$ and Coaker, 1984; Rämert, 1993; Rämert and Ekbom, 1996; Theunis sen and Schelling, 2000; L u i k et al. 2000). Therefore, limiting the use of pesticides should be mentioned among many advantages of intercropping. Intercropping also has a beneficial effect on soil structure and optimal utilization of the 
factor habitat. This creates the conditions for activating the natural mechanisms that allow obtaining high yields with good nutritional value. The following factors are important in choosing the right partner for intercropping: mutual tolerance of selected species and beneficial impact on plant health (C a r r u the r s et al. 2000; Jankow ska et al. 2009; A d a m c zew ska-S owińs ka and Ko łota, 2010).

The aim of the investigation was to determine the influence of intercropping carrot with French marigold and pot marigold on quality of carrot yield and on damage caused by some pests of carrots.

\section{MATERIALS AND METHODS}

The research was carried out in 2003-2004 in Mydlniki near Kraków (Poland), on brown soil developed from loess. A randomized block design was used in three replications on $10.13 \mathrm{~m}^{2}$ plots. The combinations of the experiment included three treatments: sole cropping of carrot (Daucus carota L.) 'Nandrin $\mathrm{F}_{1}$ ' (control plot), intercropping carrot with French marigold (Tagetes patula nana L.) 'Kolombina', and intercropping carrot with pot marigold (Calendula officinalis L.) 'Promyk'. Carrot was sown in rows with interrow distances of $67.5 \mathrm{~cm}$ (the standard seeding rate of $2.5 \mathrm{~kg}$ per $1 \mathrm{ha}$ ). French or pot marigold was sown in rows between each carrot row, depending on the treatment. All species were sown on April $16^{\text {th }}, 2003$, and on April 23 $3^{\text {rd }}$, 2004. Mineral fertilization was applied before sowing. It was quantified according to the results of the chemical analysis of the soil samples and supplemented to a level recommended for carrot: 140 $\mathrm{mg} \mathrm{N}, 80 \mathrm{mg} \mathrm{P}, 120 \mathrm{mg} \mathrm{K}$, and $80 \mathrm{mg} \mathrm{Mg}$ per $1 \mathrm{dm}^{3}$ (Sady 2000). The plots were hand weeded regularly.
The roots were harvested on September $17^{\text {th }}, 2003$, and on September $30^{\text {th }}, 2004$. After harvest, leaf length as well as root length and diameter were assessed on thirty randomly selected carrot plants from each plot. Total and marketable yield were also estimated. In the roots selected from marketable yield, dry matter content (drying method), total sugars (anthrone method by Yemm and Wills 1954), and carotenoids (colorimetric method with $96 \%$ ethyl alcohol by Lichtenthaler and Wellburn) were estimated. Separation of means was performed with t-Student test, with $=0.05$. During harvest, the weight of roots damaged by the carrot rust fly, root aphid and nematodes was analyzed. The number of carrot psyllid larvae was counted twice during the growing period. Duncan's multiple test $(<0.05)$ was used for statistical analysis of the results.

\section{RESULTS AND DISCUSSION}

The effect of intercropping carrot with French marigold and pot marigold on the quality of carrot yield varied in different years of investigation. In 2003 intercropping had no influence on carrot leaf length, root length and diameter. In 2004 carrots intercropped with French marigold had the longest roots of the maximum diameter (Table 1). Their length and diameter increased in relation to those intercropped with pot marigold about $9.8 \%$ and $10.2 \%$, while in relation to the sole crop of carrot this increase was about $4 \%$ and $6 \%$, respectively. In both years of investigation, there was no impact of intercropping on leaf length in carrot. Several factors, such as competition among crops, type of cultivar, and spatial arrangement of planting can have a significant impact on the rate of growth of component crops ( $\mathrm{N}$ e t o et al. 2010).

Table 1

The effect of carrot intercropping with French marigold and pot marigold on chosen morphological carrot features

\begin{tabular}{lccccccccc}
\hline \multirow{2}{*}{ Type of cultivation } & \multicolumn{3}{c}{ Leaf length $(\mathrm{cm})$} & \multicolumn{3}{c}{ Root length $(\mathrm{cm})$} & \multicolumn{3}{c}{ Root diameter $(\mathrm{cm})$} \\
\cline { 2 - 9 } & 2003 & 2004 & Mean & 2003 & 2004 & Mean & 2003 & 2004 & Mean \\
\hline Carrot (sole crop) & $39.13 \mathrm{a}$ & $45.96 \mathrm{a}$ & $42.55 \mathrm{a}$ & $20.65 \mathrm{a}$ & $19.56 \mathrm{~b}$ & $20.11 \mathrm{a}$ & $4.10 \mathrm{a}$ & $3.94 \mathrm{ab}$ & $4.02 \mathrm{~b}$ \\
Carrot with French marigold & $39.70 \mathrm{a}$ & $47.61 \mathrm{a}$ & $43.66 \mathrm{a}$ & $21.57 \mathrm{a}$ & $20.39 \mathrm{c}$ & $20.98 \mathrm{a}$ & $4.12 \mathrm{a}$ & $4.20 \mathrm{~b}$ & $4.16 \mathrm{~b}$ \\
Carrot with pot marigold & $41.08 \mathrm{a}$ & $43.71 \mathrm{a}$ & $42.40 \mathrm{a}$ & $20.63 \mathrm{a}$ & $18.38 \mathrm{a}$ & $19.51 \mathrm{a}$ & $3.75 \mathrm{a}$ & $3.77 \mathrm{a}$ & $3.76 \mathrm{a}$ \\
\hline
\end{tabular}

Means followed by the same letter within a column are not significantly different $(=0.05)$

In 2003 the cultivation of carrots intercropped with French marigold and pot marigold did not affect total yield (Table 2), while marketable yield increased in the intercropped plots, being the highest in the treatments with French marigold. In 2004 lower total yield was harvested in the intercropped plots compared to sole cropping and there was no effect of intercropping on marketable yield of carrot roots. To sum up, on average intercropping did not reduce total or marketable yield in the study years. The investigations of $\mathrm{Og} \mathrm{b} \mathrm{u}$ - ehi and Orzolek (1987) show the beneficial effect of intercropping on vegetable yields, which confirms the results obtained in this experiment in 2003. Yields in an intercropping system highly depend on mutual competition of chosen components, climatic conditions during the growing season in particular years and sowing date of the components (Poniedziałek and K u n i cki, 1995; A d a m c zew ska-Sowińska and Kołota, 2010; Jędrszczyk and Poni ed zi ał e k, 2007). 
Table 2

The effect of carrot intercropping with French marigold and pot marigold on carrot yield $\left(\mathrm{t} \times \mathrm{ha}^{-1}\right)$

\begin{tabular}{lcccccc}
\hline \multirow{2}{*}{ Type of cultivation } & \multicolumn{3}{c}{ Total yield } & \multicolumn{3}{c}{ Marketable yield } \\
\cline { 2 - 7 } & 2003 & 2004 & Mean & 2003 & 2004 & Mean \\
\hline Carrot (sole crop) & $44.67 \mathrm{a}$ & $72.14 \mathrm{~b}$ & $58.41 \mathrm{a}$ & $10.18 \mathrm{a}$ & $29.27 \mathrm{a}$ & $19.73 \mathrm{a}$ \\
Carrot with French marigold & $42.99 \mathrm{a}$ & $52.01 \mathrm{a}$ & $47.50 \mathrm{a}$ & $26.96 \mathrm{~b}$ & $22.17 \mathrm{a}$ & $24.57 \mathrm{a}$ \\
Carrot with pot marigold & $45.62 \mathrm{a}$ & $39.51 \mathrm{a}$ & $42.57 \mathrm{a}$ & $20.02 \mathrm{~b}$ & $23.08 \mathrm{a}$ & $21.55 \mathrm{a}$ \\
\hline
\end{tabular}

Means followed by the same letter within a column are not significantly different $(=0.05)$

In the present investigation, dry matter, total sugar and carotenoid content depended on the year and type of cultivation (Table 3). Intercropping did not affect the content of dry matter in carrot roots, except for the carrot intercropped with pot marigold in 2004 in which dry matter content was significantly higher. Total sugar and carotenoid content were higher in carrot ro- ots intercropped with both French and pot marigold, but the differences depended on the year of cultivation. Similarly, Adamczewska-S owińska and Kofota (2010) found that intercropping eggplant with white clover and perennial ryegrass did not affect the content of dry matter, vitamin $\mathrm{C}$, reducing sugars and macroelements in its fruits.

Table 3

The effect of carrot intercropping with French marigold and pot marigold on the level of chosen root components

\begin{tabular}{lrrrrrrrrc}
\hline \multirow{2}{*}{ Type of cultivation } & \multicolumn{3}{c}{ Dry matter (\% d.w.) } & \multicolumn{3}{c}{ Total sugars (\% d.w.) } & \multicolumn{3}{c}{ Carotenoids (mg $\times \mathrm{g}^{-1}$ d.w.) } \\
\cline { 2 - 10 } & 2003 & 2004 & Mean & 2003 & 2004 & Mean & 2003 & 2004 & Mean \\
\hline Carrot (sole crop) & $9.43 \mathrm{a}$ & $9.41 \mathrm{a}$ & $9.42 \mathrm{a}$ & $4.10 \mathrm{a}$ & $4.30 \mathrm{a}$ & $4,20 \mathrm{a}$ & $0.13 \mathrm{a}$ & $0.13 \mathrm{a}$ & $0.13 \mathrm{a}$ \\
Carrot with French marigold & $9.71 \mathrm{a}$ & $10.34 \mathrm{a}$ & $10.03 \mathrm{a}$ & $5.04 \mathrm{ab}$ & $5.16 \mathrm{a}$ & $5.10 \mathrm{~b}$ & $0.14 \mathrm{a}$ & $0.15 \mathrm{~b}$ & $0.15 \mathrm{a}$ \\
Carrot with pot marigold & $10.33 \mathrm{a}$ & $11.99 \mathrm{~b}$ & $11.16 \mathrm{a}$ & $5.27 \mathrm{~b}$ & $4.69 \mathrm{a}$ & $4.98 \mathrm{ab}$ & $0.14 \mathrm{a}$ & $0.16 \mathrm{~b}$ & $0.15 \mathrm{a}$ \\
\hline
\end{tabular}

Means followed by the same letter within a column are not significantly different $(=0.05)$

In the present research, carrot roots were infested by the carrot rust fly (CRF), Psila rosae (F.), root aphid, Pemphigus phenax B\&B, and nematodes. Larvae of the carrot psyllid, Trioza viridula Zett., were noted on carrot leaves. These species cause significant economic losses in Poland (M i c h a li k and Wiech, 2000; S zwejda and Wrzodak, 2007). The largest number of roots damaged by the carrot rust fly was obtained in the control plots (sole cropping) (Table 4). In both years of observation the number of carrot psyllid larvae on carrot plants growing in the plots with French marigold and pot marigold was significantly lower compared with the sole carrot crop (Table 5). In the initial orientation of pests to the host, olfactory stimuli from the carrot plant seem to be the most important. CRF and other carrot pests are attracted to chlorgenic acid (Cole et al. 1988). Attractiveness of carrot cultivars to pests varies $(\mathrm{Mich}$ a li k and $\mathrm{W}$ i e c h, 2000; Ł u c z a k, 2007). The proximity of plants that are non-host may mask the scent of the host plant, which hinders finding it. Intercropping seems to have a large effect on insects that oviposit in the soil, such as the carrot fly Psila rosae (R ä m e r t, 1996; Rämert and Ekbom, 1996). Numerous studies have shown that intercropping carrots with a cover crop reduces carrot rust fly damage ( $\mathrm{R}$ ä $\mathrm{m}$ e $\mathrm{rt}$, 1993; Rämert and Ekbom, 1996; Theunis- sen and Schelling, 2000). Luik et al. (2000) found that intercropping of carrots with garden beans significantly disoriented pests and decreased the damage of carrots by Psila rosae and Trioza viridula. Uvah and Coaker (1984) noted that mixed cropping carrots with onions reduced attacks by carrot fly. Marigold (Tagetes spp.), which is a popular bedding plant, can be used as such cover crop. Fin ch et al. (2003) studied three marigold species which reduced the number of eggs laid by cabbage root fly females. Jankowska et al. (2009) found a significant reduction in the number of cabbage pests in plots where cabbage was intercropped with Tagetes and Calendu$l a$. The use of plants to provide nectar and pollen resources to natural enemies through habitat management is a growing focus of conservation biological control. J a n k o w s k a $(2007,2010)$ found that in plots where cabbage was intercropped with French marigold and pot marigold aphid parasitizing, number of predatory syrphids and role of diamondback moth parasitoids were greater.

In the years 2003 and 2004, a distortion of the root structure and typical nematode damage symptoms were observed. Carrots affected by nematodes often exhibit forking of the taproot, stubbing of the roots as well as unsightly galls on the taproot and secondary roots. A smaller number of damaged roots was 
recorded in the plots where carrot was intercropped with pot marigold. These differences were significant not only in relation to the sole crop but also in relation to intercropping with French marigold (Table 4). Mari- gold (Tagetes spp.) was one of the first plants reported to be highly resistant to root-knot nematodes ( $\mathrm{P} 1$ o e g , 2002). Also S zakiel et al. (2008) noted that marigolds had an overall suppressive effect on nematodes.

Table 4

The influence of intercropping on the occurrence of some pests on carrot roots

\begin{tabular}{|c|c|c|c|c|c|c|c|}
\hline \multirow{3}{*}{ Type of cultivation } & \multicolumn{7}{|c|}{ Roots infested by pests (\%) } \\
\hline & \multicolumn{3}{|c|}{$\begin{array}{c}\text { Carrot fly } \\
\text { Psila rosae }\end{array}$} & \multicolumn{3}{|c|}{ Nematodes } & $\begin{array}{c}\text { Root aphid } \\
\text { Pemphigus phenax }\end{array}$ \\
\hline & 2003 & 2004 & Mean & 2003 & 2004 & Mean & 2003 \\
\hline Carrot (sole crop) & $46.50 \mathrm{~b}$ & $42.00 \mathrm{~b}$ & $44.25 \mathrm{~b}$ & $5.50 \mathrm{c}$ & $23.33 \mathrm{c}$ & $14.42 \mathrm{c}$ & $5.46 \mathrm{a}$ \\
\hline Carrot with French marigold & $15.60 \mathrm{a}$ & $18.66 \mathrm{a}$ & $17.13 \mathrm{a}$ & $1.50 \mathrm{~b}$ & $11.33 \mathrm{~b}$ & $6.42 \mathrm{~b}$ & $12.00 \mathrm{~b}$ \\
\hline Carrot with pot marigold & $36.10 \mathrm{ab}$ & $21.00 \mathrm{a}$ & $28.55 \mathrm{a}$ & $0.30 \mathrm{a}$ & $2.66 \mathrm{a}$ & $1.48 \mathrm{a}$ & $33.30 \mathrm{c}$ \\
\hline
\end{tabular}

Means followed by the same letter within a column are not significantly different $(<0.05)$

Table 5

The influence of intercropping on the occurrence of carrot psyllid (T. viridula) on analyzed plants

\begin{tabular}{lcccccc}
\hline & \multicolumn{5}{c}{$\begin{array}{c}\text { Carrot psyllid } \\
\text { Trioza viridula Zett }\end{array}$} \\
\cline { 2 - 6 } \multicolumn{1}{c}{ Type of cultivation } & \multicolumn{5}{c}{ No./10 plants } \\
\cline { 2 - 7 } & 2003 & 2004 & Mean & 2003 & 2004 & Mean \\
\cline { 2 - 7 } & 14 VII & 15 VII & VII & 13 VIII & 16 VIIII & VIII \\
\hline Carrot (sole crop) & $2.00 \mathrm{~b}$ & $3.00 \mathrm{~b}$ & $2.50 \mathrm{~b}$ & $5.33 \mathrm{~b}$ & $7.00 \mathrm{~b}$ & $6.20 \mathrm{~b}$ \\
Carrot with French marigold & $0.33 \mathrm{a}$ & $1.00 \mathrm{a}$ & $0.66 \mathrm{a}$ & $1.66 \mathrm{a}$ & $2.66 \mathrm{a}$ & $2.20 \mathrm{a}$ \\
Carrot with pot marigold & $0.33 \mathrm{a}$ & $1.00 \mathrm{a}$ & $0.66 \mathrm{a}$ & $1.66 \mathrm{a}$ & $2.66 \mathrm{a}$ & $2.20 \mathrm{a}$ \\
\hline
\end{tabular}

Means followed by the same letter within a column are not significantly different $(<0.05)$

\section{CONCLUSIONS}

1. Intercropping did not have a decreasing effect on total and marketable carrot yield.

2. Intercropping had a positive influence on total sugar content in carrot roots.

3. There was no effect of intercropping on the level of dry matter and carotenoid content.

4. Intercropping had a significant effect on decreasing the number of roots damaged by the carrot rust fly, Psila rosae, (the best in this respect was the combination with Tagetes) and by nematodes (the best in this respect was the combination with Calendula) and decreasing the number of larvae of carrot psyllid, Trioza viridula.

5. In 2003 intercropping was not found to have a positive effect on reducing the occurrence of the root aphid.

\section{Acknowledgements}

Research supported by the Ministry of Science and Higher Education of Poland as the part of statutory activities of Department of Vegetable and Medicinal Plants and Department of Plant Protection, University of Agriculture, DS-3500/WO/.

\section{REFERENCES}

Adamczewska-Sowińska K., Kołota E. 2010. Yielding and nutritive value of field cultivated eggplant with the use of living and synthetic mulches. Acta Sci. Pol., Hortorum Cultus. 9(3): 191-199.

Andow D.A. 1991. Vegetational diversity and arthropod population response. Ann. Rev. Entomol. 36: 561-568. http://dx.doi.org/10.1146/annurev.ento.36.1.561

Carruthers K., Prithiviraj B., Fe Q., Cloutier D., Martin R.C., Smith D.L. 2000. Intercropping corn with soybean, lupin and forages: yield component responses. Eur. J. Agronomy. 12: 103-115. http://dx.doi. org/10.1016\%2FS1161-0301\%2899\%2900051-9

Cole R.A., Phelps K., Ellis P.R. 1988. Further studies relating chlorogenic acid concentration in carrots to carrot fly damage. Ann. of Appl. Biol. 112: 13-18. http:// dx.doi.org/10.1111\%2Fj.1744-7348.1988.tb02036.x

Finch S., Billiad H., Collier R.H.2003. Companion planting - do aromatic plants disrupt host - plant finding by the cabbage root fly and the onion fly more effectively than non-aromatic plants. Entomol. Exp. Appl. 109: 183-195. http://dx.doi.org/10.1046\%2Fj.0013-8703.20 03.00102.x

J a n k ow s ka B . 2007. Impact of intercropping white cabbage with Pot Marigold (Calendula officinalis L.) and French 
Marigold (Tagetes patula nana) on the occurrence of cabbage aphid (Brevicoryne brassicae L.), its parasitoid Diaeretiella rapae M'Intosh and predatory Syrphidae. Aphids and Other Hemipterous Insects. 13: 199-209.

Jankowska B. 2010. Effect of intercropping white cabbage with French Marigold (Tagetes patula nana) and Pot Marigold (Calendula officinalis) on population density of diamondbath moth DBM (Plutella xylostella) and it's parasitoid complex. Veg. Crops Res. Bull. 73: 107-117.

Jankowska B., Poniedziałek M., Jędrszczyk E. 2009. Effect of intercropping white cabbage with French Marigold (Tagetes patula nana) and Pot Marigold ( $\mathrm{Ca}$ lendula officinalis L.) on the plants colonization by herbivorous pest insects. Folia Hort. 21(1): 95-103.

Jędrszczyk E., Poniedziałek M. 2007. The influence of meteorological conditions on the growth and yielding of leek cultivated in living mulches. Folia Hort. 19/2: 23-37.

Luik A., Heidemaa M., Viidalepp V. 2000. The influence of intercropping and raw dust mulching on carrot yield and entomofauna. Transactions of the Estonian Agric. Univ, Agronomy. 208: 115-120.

Łuczak I. 2007. Occurrence of carrot psyllid (Trioza viridula Zett.) on various carrot and parsley cultivars. Prog. Plant Protection / Post. Ochr. Roślin. 47(1): 310-313.

Michalik B., Wiech K. 2000. Differences in the resistance of carrot lines and cultivars to carrot fly (Psila rosae (Fabr.)) attack. Folia Hort. 12(2): 43-51.

Neto F.B., Gomes E.G., Araujo R.R. Oliveira E.Q., Sousa Nunes G.H., Grangeiro L.C., Silveira Borges Azevedo C.M. 2010. Evaluation of yield advantage indexes in carrot-lettuce intercropping systems. J. Appl. Ecol. 39(3): 416-426.

Ogbuehi C.R.A., Orzolek M.D. 1987. Intercropping carrot and sweetcorn in a multiple cropping system. Scientia Hort. 31: 17-24. http://dx.doi.org/10.1016\%2F0 304-4238\%2887\%2990102-6

Ploeg A. 2002. Effect of selected Marigold varieties on rootknot nematodes and tomato and melon yields. Plant Dis. 86: 505-508. http://dx.doi.org/10.1094\%2FPDIS.2002. 86.5 .505

Poniedziałek M., Kunicki E. 1995. Przydatność kilku odmian fasoli karłowej szparagowej do uprawy współrzędnej z kapustą późną. / Usefulness of several dwarf bean cultivars for intercropping with late cabbage. Zesz. Nauk. AR w Krakowie 302. Ogrodnictwo, 22, 5-16. (in Polish)

Rämert B. 1993. Mulching with grass and bark and intercropping with Medicago littoralis against carrot rust fly (Psila rosae). Biol. Agric. Hort. 9: 125-135. http:// dx.doi.org/10.1080\%2F01448765.1996.9754794

Rämert B. 1996. Intercropping as a strategy for reducing damage to carrots caused by the carrot fly, Psila rosae. Biol. Agric. Hort. 13: 359-369.

Rämert B., Ekbom B. 1996. Intercropping as a management strategy against carrot rust fly (Diptera: Psilidae): A test of enemies and resource concentration hypothesis. Environ. Entomol. 25(5): 1092-1100.
S ady W. 2000. Nawożenie warzyw polowych. Plantpress, Kraków: 78. (in Polish)

Szakiel A., Ruszkowski D., Grudniak A., Kurek A., Wolska K., Doligalska M., Janiszewska W. 2008. Antibacterial and Antiparasitic Activity of Oleanolic Acid and its Glycosides isolated from Marigold (Calendula officinalis). Planta Medica, 74: 1709-1715. http://dx.doi.org/10.1055\%2Fs-0028-1088315

Szwejda J., Wrzodak R. 2007. Phytophagous entomofauna occurring on carrot and plant protection methods. Veg. Crops Res. Bull. 67: 95-102. http://dx.doi. org/10.2478\%2Fv10032-007-0034-4

Theunissen J., Schelling G. 2000. Undersowing carrots with clover: suppression of carrot rust fly (Psila rosae) and cavity spot (Phytium spp.) infestation. Biol. Agric. Hortic. 18: 67-76.

Uvah I.I.I., Coaker T.H. 1984. Effect of mixed cropping on some insect pests of carrots and onions. Entomol. Exp. Appl. 36(2): 159-167. http://dx.doi.org /10.1111\%2Fj.1570-7458.1984.tb03422.x

Yem m E.W., Wills A.J. 1954. The estimation of carbohydrates in plant extracts by anthrone. Biochem. J. 57: 508-514.

\section{Wpływ uprawy współrzędnej marchwi (Daucus carota L.) $\mathrm{z}$ aksamitką (Tagetes patula nana $\mathrm{L}$.) i nagietkiem (Calendula officinalis L.) na występowanie szkodników oraz wysokość i jakość plonu marchwi}

\section{Streszczenie}

Uprawy współrzędne, wykorzystujące różne aspekty wzajemnego oddziaływania na siebie organizmów w ekosystemach, można zaliczyć do metod pro-ekologicznych, ograniczających szkodliwą ingerencję człowieka w środowisko, a przede wszystkim zużycie środków chemicznych. Pozwalają również osiągnąć wysoki plon, dobrą jakość i wydajność ekonomiczną. Badania prowadzone w latach 2003-2004 w Mydlnikach, k. Krakowa miały na celu określenie wpływu uprawy współrzędnej marchwi 'Nandrin $\mathrm{F}_{1}$ ' $\mathrm{z}$ aksamitką (Tagetes patula nana L.) 'Kolombina' i nagietkiem (Calendula officinalis L.) 'Promyk' na wielkość i jakość plonu marchwi oraz stopień porażenia roślin przez szkodniki. Średnio dla obu lat badań nie stwierdzono obniżenia plonu ogólnego i handlowego marchwi pod wpływem uprawy współrzędnej. W 2003 roku uprawa współrzędna wpłynęła na znaczne zwiększenie plonu handlowego w porównaniu $\mathrm{z}$ plonem w uprawie jednorodnej. W 2004 obserwowano wyższą zawartość suchej masy w korzeniach marchwi uprawianej współrzędnie 
z nagietkiem. Pod wpływem uprawy współrzędnej, zarówno z aksamitką jak i nagietkiem obserwowano wzrost zawartości cukrów w korzeniach marchwi, a w 2004 roku karotenoidów.

Stwierdzono znaczący wpływ uprawy współrzędnej na liczbę uszkodzonych korzeni przez połyśnicę marchwiankę Psila rosae (najlepsza pod tym względem była kombinacja $\mathrm{z}$ aksamitką) i nicienie (najlepsza okazała się kombinacja z nagietkiem). Na poletkach z uprawą współrzędną marchwi stwierdzono istotnie mniejszą liczbę larw golanicy zielonki Trio$z a$ viridula. Nie stwierdzono pozytywnego wpływu na obniżenie zasiedlenia korzeni przez bawełnicę topolowo-marchwianą. 